\title{
Infection with Helicobacter Pylori Presenting the vacA s2m2 haplotype is Strongly Associated with Protection Against Gastric Cancer
}

\author{
Alix Guevara-Tique \\ University of Tolima \\ Fabian Castro Valencia \\ University of Tolima \\ John Jairo Suaréz Olaya \\ University of Tolima \\ Roberto Carlos Torres \\ Mexican Social Security Institute \\ Giovanna Parra \\ University of Tolima \\ Isabel Serrano \\ Hospital Federico Lleras Acosta \\ Javier Torres \\ Mexican Social Security Institute \\ Luis Carvajal \\ University of California, Davis \\ Magdalena Echeverry Polanco \\ University of Tolima \\ Mabel Bohórquez ( $\nabla$ mebohorquez@ut.edu.co ) \\ University of Tolima
}

\section{Research Article}

Keywords: Helicobacter pylori, pathogenicity, gastric neoplasms, gastric diseases, virulence genes, epidemiology

Posted Date: March 1st, 2021

DOI: https://doi.org/10.21203/rs.3.rs-250522/v1

License: (c) (1) This work is licensed under a Creative Commons Attribution 4.0 International License. Read Full License 


\section{Abstract}

Background: Infection with Helicobacter pylori is recognized as the main risk factor for gastric cancer (GC); the clinical outcome of this infection is variable and partially depends on the virulence of the infective strain. This study characterizes $H$. pylori virulence genes in patients with diverse gastric lesions, from preneoplasia to GC, from a South American region with high GC mortality rates.

Methods: We studied the virulence profiles of $H$. pylori strains to colonize the antrum of 318 patients with non-atrophic gastritis (NAG), 58 patients with preneoplastic lesions (PN), and 90 with GC from Ibagué, Colombia. The presence of $16 S$ rDNA, the cagA and $\operatorname{cag} E$ genes, and the vacA $s_{1}, s_{2}, m_{1}$, and $m_{2}$ alleles were determined by PCR.

Results: H. pylori infection was detected in $44 \%$ of all patients, $41.2 \%$ in NAG, $43.1 \%$ in PN and $54.4 \%$ of GC patients $(p=0.0813)$. cagA and cagE genes were significantly more frequent in and GC than in NAG $(p=$ $<.0001)$. The vacA $s_{1} m_{1}$ haplotype was significantly more frequent in PN (68\%) and GC (65.3\%) than in NAG $(37.4 \%)$. The frequency of $v a c A s_{2} m_{2}$ haplotype decreased significantly from NAG $(42.7 \%)$ to PN $(12 \%)$ and this to GC (4.1\%). A total of 23 different genotypes were identified, with cagA+/ cagE+/ vacA $s_{1} m_{1}(84 / 205)$ as the more frequent in PN and GC and cagA-/cagE-/vacA $s_{2} m_{2}$ in NAG (49/205).

Conclusions: In the population studied, $\operatorname{vacA} s_{2} m_{2}$ was identified as a significant marker for protection against $\mathrm{PN}$ and $\mathrm{GC}$, and genotype cagA+/cagE+/vacA $s_{1} m_{1}$ as a marker for increased GC risk. We also found that patients with $\mathrm{PN}$ and GC had a higher frequency of cagAt/cagE+/vacA $s_{1} m_{1} H$. pylori strains known to be aggressive.

\section{Background}

Gastric cancer (GC) is the third leading cause of cancer-related deaths worldwide. ${ }^{1,2,3}$ In Colombia, it is the leading cause of cancer-related deaths in men and the fourth in women. ${ }^{4,5}$ Globally, the GC incidence varies across different countries; in Latin America, an association between altitude and GC risk has been observed and Chile, Costa Rica, and Colombia are some of the countries with the highest mortality rates in the world. ${ }^{4}$

The bacteria Helicobacter pylori (H. pylori) is classified as a class I human carcinogen and recognized as the main risk factor for GC. 6,7 This bacteria promotes inflammation of the gastric mucosa that in some patients lead to premalignant lesions such as chronic atrophic gastritis, intestinal metaplasia, and dysplasia that precedes the appearance of GC. ${ }^{6-13}$ Worldwide, there is no correlation between the prevalence of $H$. pylori infection and GC incidence. ${ }^{14}$ This bacterium colonizes the gastric mucosa of $50 \%$ of the worldwide population and $80 \%$ in developing countries; still, only $1-3 \%$ of infected people develop premalignant gastric pathologies. ${ }^{9,15,16}$

In Colombia, whereas the prevalence of $H$. pylori infection varies widely between regions, ${ }^{14,17-19}$ the mortality of GC as well as a higher prevalence of precancerous lesions are concentrated in the central part of the country that corresponds to the Andes Central Mountain Range, mainly in the Coffee axis 
departments (Caldas, Risaralda, and Quindío), Norte de Santander, Boyacá, Huila, Cauca, Tolima, and Caquetá. Furthermore, the lowest GC mortality rates are reported in regions with low altitudes but a high prevalence of infection, such as the Guajira, Chocó, Córdoba, Putumayo, and Sucre departments. ${ }^{12}$ Several theories have been raised regarding the association between altitude and GC, but they have not been well elucidated yet. It is likely that those mountain regions cluster host genetic, dietary, and environmental factors as well as bacterial genotypes that promote GC development. ${ }^{8,11-13,20-25}$ Among the best-studied $H$. pylori virulence factors are cytotoxin-associated gene $\mathrm{A}(\operatorname{cag} A)$ and vacuolating cytotoxin gene $\mathrm{A}(\operatorname{vac} A)$. More virulent strains carry the $\operatorname{cag} A$ gene, which encodes the oncoprotein CagA, which induces a myriad of changes in the gastric mucosa: an increase of inflammation, the loss of epithelial polarity, the disruption of intercellular junctions, increases proliferation, reduces apoptosis, and eventually promotes carcinogenicity. ${ }^{26-28}$ The vacA gene, which is virtually present in all $H$. pylori strains, encodes the VacA protein, which is responsible for cytoplasmic vacuoles and pores in the membrane of gastric epithelial cells and apoptosis. ${ }^{29-31}$ Some vacA alleles are known to increase the risk of developing peptic ulcer disease and GC. ${ }^{32-36}$ Infection with $H$. pylori strains that possess the vacA $s_{1} m_{1}$ genotype is associated with an increased risk of peptic ulceration and GC. ${ }^{27,32,37-39}$ However, little attention has been paid to evaluate the prognostic value of the $v a c A s_{2} m_{2}$ haplotype.

In the Tolima Department of Colombia, a central mountainous region with high GC mortality rates, H. pylori infection prevalence varies between $59 \%$ and $66 \%$ but the correlation between the bacterial genotypes and gastric lesions has not been properly studied. . $^{32,40-42}$

\section{Methods}

In this study, we characterized $H$. pylori virulence genes in patients with NAG, PN, or GC from Tolima, with a particular interest in the study of $\operatorname{vacA} s_{2} m_{2}$ haplotype.

\section{Patients and sampling}

A total of 466 patients with gastric pathologies were recruited during the period 2010-2019 in Ibagué, including 90 patients with GC who had undergone upper gastrectomy at the Federico Lleras Acosta Hospital and 376 patients who had undergone upper gastrointestinal endoscopy as part of the dyspepsia study at the Javeriano Medical Center. A gastric biopsy from the pyloric antrum region was taken from each patient, placed in $70 \%$ alcohol solution, and stored at $-20^{\circ} \mathrm{C}$ until studied. Biopsies from antrum and tumor lesions were placed in paraformaldehyde for histology studies. All patients were informed about the study and if willing to participate they were asked to sign an informed consent letter. The research protocol used in the study was approved by the University of Tolima Ethics Committee and adhered to the Helsinki Declaration.

\section{Histopathological examinations}

Biopsies in paraformaldehyde were embedded in paraffin for histopathological diagnosis. Antral and tumor sections were stained with hematoxylin and eosin and evaluated independently by three surgical pathologists to establish the diagnosis in each case. Patients were assigned to one of the three groups: 1 . 
chronic non-atrophic gastritis (NAG); 2. PN, which included patients with chronic and atrophic gastritis, intestinal metaplasia, and dysplasia; and 3. GC.

\section{Molecular identification of $\mathrm{H}$. pylori}

DNA was extracted from the gastric antrum biopsy specimens with the DNeasy Blood and Tissue Kit (QIAGEN, USA) following the manufacturer's instructions. DNA was quantified using a Nanodrop ND ${ }^{\mathrm{TM}} 1000$ UV-Vis spectrophotometer of Thermo Scientific and quality was evaluated by using the ratio of absorbance at 260 and $280 \mathrm{~nm}$ (A260/A280). To test for the presence of H. pylori, a 537-bp fragment of the Sub unit 16 of ribosomal DNA (16Ss rDNA) gene was amplified using polymerase chain reaction (PCR) with the primers ACT-1 and ACT-2, as previously described (ref). DNA extracted from the H. pylori NCTC 11638 strain (donated by the National Institute of Cancerology, Bogotá, Colombia) was used such as positive control. Ultrapure water instead of DNA was used such as negative control. The final volume of $25 \mu$ contained 9.5 $\mu \mathrm{l}$ of ultrapure water, $1 \mu \mathrm{l}$ of each primer, $12.5 \mu \mathrm{l}$ of the BIOLINE MyTaq ${ }^{\text {TM }}$ Extract from the PCR kit, and $1.5 \mu \mathrm{l}$ of DNA. The thermocycling program was previously described by López et al. ${ }^{40}$

\section{Amplification and typing of the cagA, cagE, and vacA genes}

To determine the genotype of $H$. pylori virulence genes the samples were subjected to PCR for the $c a g A$ and cagE genes and the signal regions ( $s_{1}$ and $s_{2}$ alleles) and mid-region $\left(m_{1}\right.$ and $m_{2}$ alleles) of vacA using primers and conditions previously described. ${ }^{33,40,43}$ As a control for one possible inhibition of the reaction, a fragment from the human $\beta$-globin gene was amplified. All PCRs were performed in a Bio-Rad Dual-Touch

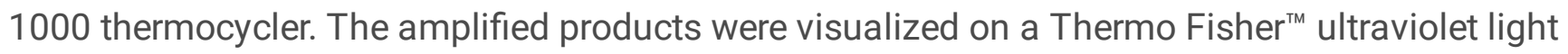
transilluminator on $1.5 \%$ agarose gels at 100 volts for 60 minutes using ethidium bromide (0.4\%). All primers used in this study are listed in Supplementary table 1, Additional File 1.

\section{Statistical methods}

The chi-square $\left(X^{2}\right)$ independence tests were performed to evaluate differences between the epidemiological variables, the presence of $H$. pylori infection, and the bacterial genotypes, and the gastric pathology of the patients. A two-tailed p-value (a) $<0.05$ was considered statistically significant. The data were processed with $\mathrm{R}$ software version 3.6.1.

\section{Results}

A total of 466 patients with different gastric pathologies were included in this study. There were 285 women (61.2\%) and 181 men (38.8\%), with an average age of $52.1 \pm 16$ years. A 2:1 ratio of women to men was observed in patients with premalignant pathologies, while in patients with GC, this proportion was reversed (2:1 ratio of men to women) (Figure 1$)$.

The histological analysis showed NAG in 318 (68.2\%), PN in 58 (12.5\%) and GC in 90 (19.3\%) patients. Of the patients with GC, 40 (44.4\%) had intestinal-type GC (GCI), 25 (27.8\%) had diffuse-type GC (GCD) and 25 (27.8\%) had mixed-type GC (GCM). Among the $40 \mathrm{GCl}$ cases 27 (67.5\%) were men; of the 25 GCD cases 17 (68\%) were men and of the 25 GCM cases 18 (72\%) were men. 
The molecular diagnosis tests showed that $44 \%(205 / 466)$ of the patients were infected with $\mathrm{H}$. pylori, $59.5 \%$ (122/205) were women and $40.5 \%$ (83/205) were men. The H. pylori prevalence was lower than $50 \%$ in most gastric histological lesions, except in GC (54.4\%). The infection status was not associated with the sex, age, or gastric pathology of the patients. The molecular diagnosis results are presented in Table 1.

Table 1

Molecular detection of $H$. pylori in 466 antral gastric tissue.

\begin{tabular}{|c|c|c|c|c|}
\hline \multirow[t]{2}{*}{ Variable } & \multirow[t]{2}{*}{ Population $\mathrm{n}^{\dagger}(\%)$} & \multicolumn{2}{|c|}{ H. pylori detection ${ }^{\ddagger}$} & \multirow[t]{2}{*}{ p-value } \\
\hline & & Negative & Positive & \\
\hline \multicolumn{5}{|l|}{ Sex } \\
\hline Female & $285(61.2)$ & $163(57.2)$ & $122(42.8)$ & \multirow[t]{2}{*}{0.5839} \\
\hline Male & $181(38.8)$ & $98(54.1)$ & $83(45.9)$ & \\
\hline \multicolumn{5}{|l|}{ Age } \\
\hline$<50$ years & $187(40.1)$ & $90(48.1)$ & $97(51.9)$ & \multirow[t]{2}{*}{$<.0001^{\star}$} \\
\hline$\geq 50$ years & $279(59.9)$ & $171(61.3)$ & $108(38.7)$ & \\
\hline \multicolumn{5}{|l|}{ Pathology§ } \\
\hline NAG & $318(68.2)$ & $187(58.8)$ & $131(41.2)$ & 0.0813 \\
\hline PN & $58(12.5)$ & $33(56.9)$ & $25(43.1)$ & \\
\hline $\mathrm{GC}$ & $90(19.3)$ & $41(45.6)$ & $49(54.4)$ & \\
\hline \multicolumn{5}{|c|}{${ }^{t} \mathrm{n}(\%)$ : Number and percent in each category } \\
\hline \multicolumn{5}{|c|}{${ }^{\ddagger}$ Molecular detection of $\mathrm{H}$. pylori was performed from partial amplification of $16 S \mathrm{rDNA}$ gene } \\
\hline \multicolumn{5}{|c|}{$\begin{array}{l}\text { § The gastric pathologies of patients were classified in three categories: non-atrophic gastritis (NAG), } \\
\text { preneoplastic lesions (PN) and gastric cancer (GC) }\end{array}$} \\
\hline \multicolumn{5}{|l|}{ *p-value $<0.05$} \\
\hline
\end{tabular}

In all $H$. pylori-positive biopsies, the cagA, cagE, and vacA genes were amplified in $59.5 \%, 66.3 \%$, and $94.6 \%$ of cases, respectively (Table 2). Strains with the $\operatorname{cag} A$ and $\operatorname{cag} E$ genes were significantly more frequent in PN and GC than in NAG ( $p$-value 0.004 and $<0.0001$, respectively), and OR values showed that the presence of these genes increased around 10 times the risk for $\mathrm{GC}$. As the severity of gastric pathology increased, the proportion of strains with $\operatorname{cag} A$ and $\operatorname{cag} E$ also increased (Figure 2). These genes were present in almost $90 \%$ of $H$. pylori strains in GC, regardless of the subtype of cancer (intestinal or diffuse). 
PCR amplification of the signal regions ( $s_{1}$ and $s_{2}$ alleles) and mid-regions ( $m_{1}$ and $m_{2}$ alleles) of vacA showed different allelic combinations (Supplementary table 2, Additional File 1) with a predominance of $s_{1} m_{1}(47.8 \%)$ and $s_{2} m_{2}(29.8 \%)$. The $s_{1} m_{1}$ genotype was significantly more frequent in patients with PN lesions $(68 \%$, p-value 0.001$)$ or GC $(65.3 \%, p<0.0001)$ than in patients with NAG $(37.4 \%)$, and OR values indicated a risk for GC of 18 times higher when $s_{1} m_{1}$ is present. Besides, the $s_{2} m_{2}$ haplotype was frequent in NAG (42.7\%) but drastically decreased in PN $(12 \%$,) with an OR value of 0.1544 and was almost absent in GC cases (4.1\%) with an OR value as low as 0.0547 (Figure 2 and Table 2). 
Table 2

Status of $\operatorname{cag} A$, $\operatorname{cag} E$, and $v a c A$ genes in patients infected with $H$. pylori.

\begin{tabular}{|c|c|c|c|c|c|c|c|c|}
\hline \multirow{2}{*}{$\begin{array}{l}\text { Gene or } \\
\text { haplotype }\end{array}$} & \multirow{2}{*}{$\begin{array}{l}\text { Population } \\
\text { no. }{ }^{+}(\%)\end{array}$} & \multicolumn{4}{|c|}{ Gastric pathology§ } & \multicolumn{2}{|c|}{ NAG vs GC } & \multirow[b]{2}{*}{ OR } \\
\hline & & $\begin{array}{l}\text { NACG } \\
(\%)\end{array}$ & $\begin{array}{l}\text { PN } \\
(\%)\end{array}$ & GC (\%) & p-value & OR & p-value & \\
\hline \multicolumn{9}{|l|}{$\operatorname{cag} A$} \\
\hline Negative & $83(40.5)$ & $\begin{array}{l}72 \\
(55.0)\end{array}$ & $\begin{array}{l}6 \\
(24.0)\end{array}$ & $\begin{array}{l}5 \\
(10.2)\end{array}$ & 0.00455 & $\begin{array}{l}3.8644 \\
(1.45- \\
10.29)\end{array}$ & $<0.0001^{*}$ & $\begin{array}{l}10.739 \\
(4.01- \\
28.81)\end{array}$ \\
\hline Positive & $122(59.5)$ & $\begin{array}{l}59 \\
(45.0)\end{array}$ & $\begin{array}{l}19 \\
(76.0)\end{array}$ & $\begin{array}{l}44 \\
(89.8)\end{array}$ & & & & \\
\hline Total & 205 & 131 & 25 & 49 & & & & \\
\hline \multicolumn{9}{|l|}{$\operatorname{cag} E$} \\
\hline Negative & 69 (33.7) & $\begin{array}{l}60 \\
(45.8)\end{array}$ & $\begin{array}{l}5 \\
(20.0)\end{array}$ & $\begin{array}{l}4 \\
(8.2)\end{array}$ & 0.016489 & $\begin{array}{l}3.3803 \\
(1.19- \\
9.54)\end{array}$ & $<0.0001^{*}$ & $\begin{array}{l}9.507 \\
(3.23- \\
27.96)\end{array}$ \\
\hline Positive & $136(66.3)$ & $\begin{array}{l}71 \\
(54.2)\end{array}$ & $\begin{array}{l}20 \\
(80.0)\end{array}$ & $\begin{array}{l}45 \\
(91.8)\end{array}$ & & & & \\
\hline Total & 205 & 131 & 25 & 49 & & & & \\
\hline \multicolumn{9}{|l|}{$\operatorname{vac} A$} \\
\hline$s_{1} m_{1}$ & $98(47.8)$ & $\begin{array}{l}49 \\
(37.4)\end{array}$ & $\begin{array}{l}17 \\
(68.0)\end{array}$ & $\begin{array}{l}32 \\
(65.3)\end{array}$ & 0.001644 & $\begin{array}{l}6.4762 \\
(1.79- \\
23.43)\end{array}$ & $<0.0001^{\star}$ & $\begin{array}{l}18.2857 \\
(4.16- \\
80.26)\end{array}$ \\
\hline$s_{2} m_{2}$ & $61(29.7)$ & $\begin{array}{l}56 \\
(42.7)\end{array}$ & $\begin{array}{l}3 \\
(12.0)\end{array}$ & $\begin{array}{l}2 \\
(4.1)\end{array}$ & & $\begin{array}{l}0.1544 \\
(0.04- \\
0.55)\end{array}$ & & $\begin{array}{l}0.0547 \\
(0.0125- \\
0.24)\end{array}$ \\
\hline Total & 159 & 105 & 20 & 34 & & & & \\
\hline \multicolumn{9}{|c|}{${ }^{\dagger}$ no. (\%): number and percent in each category } \\
\hline \multicolumn{9}{|c|}{$\begin{array}{l}\text { § The gastric pathologies of patients were classified into three categories: non-atrophic gastritis (NAG), } \\
\text { preneoplastic lesions (PN), and gastric cancer (GC) }\end{array}$} \\
\hline *p-value $<0.05$ & & & & & & & & \\
\hline
\end{tabular}

A total of 23 different genotypes and one case of coinfection were identified in the infected patients (Supplementary Figure 1, Additional File 1), with a predominance of the $\operatorname{cag} A+/ \operatorname{cag} E+/ \operatorname{vacA} s_{1} m_{1}(41 \%)$ and 
cagA-/cagE-/vacA s2m2 (24\%) genotypes. Patients with NAG presented the highest variation in genotypes (21 different genotypes), followed by patients with PN (10 genotypes), patients with GCl (9 genotypes), and finally, patients with GCD and GCM (5 genotypes each); there seems to be a selection of genotypes as the disease progress. In patients with NAG, the genotypes cagA-/cagE-/vacA $s 2 m 2$ and cagAt/cagEt/vacA $s_{1} m_{1}$ were the most frequent ( 35.1 and $31.3 \%$, respectively) while in patients with PN and GC, the cagAt/cagE+/ vacA $s_{1} m_{1}$ genotype was the most prevalent (60 and $57.1 \%$, respectively). The cagA-/cagE-/vacA $s_{2} m_{2}$ genotype was present in only one patient with GC resulting in an OR value of 0.066 as compared with the NAG group (Supplementary Figure 2, Additional File 1, Supplementary table 3, Additional File 1).

\section{Discussion}

$\mathrm{GC}$ is a multifactorial disease associated with genetic, environmental, and infectious factors, with $H$. pylori infection as the more important risk factor. GC associated with $H$. pylori infection is the result of long-term chronic inflammation in the gastric mucosa that when unregulated may lead to tissue damage, which may progress to atrophic gastritis, intestinal metaplasia, dysplasia, and eventually GC. ${ }^{44,45}$ Bacterial genotypes play an important role in clinical outcomes, particularly when they are associated with an increased inflammatory response; however, this association may vary between and within different populations. ${ }^{46}$

In Colombia, the prevalence of $H$. pylori infection and the risk for GC vary among the different departments. ${ }^{10,58,60}$ The association between gastric lesions and $H$. pylori virulence factors have been evaluated in Colombian departments with a similar prevalence of infection but contrasting GC risk and higher frequencies of $\operatorname{cag} A$-positive and $\operatorname{vac} A s_{1} m_{1}$ genotypes were found in populations with a higher risk of GC than in low-risk areas. ${ }^{47-49}$ In Ibagué, located in the Andean mountain region with high GC mortality rates, ${ }^{12,13,50,51}$ only studies with small samples size have been carried out, analyzing cag $A$ and the $s$ and $m$ regions of vacA. ${ }^{40-42,52}$ In the present study we aimed to do a more comprehensive analysis of genotypes in virulence genes in larger groups of patients.

In our studied population, the most frequent type of GC was GCl (44.4\%), similar to previous works, ${ }^{55-58}$ while the frequency of GCM (27.8\%) was higher than that reported in other countries. ${ }^{70,71}$ of note, $20 \%$ of the GC patients had an average age of diagnosis of 42 years, which shows the need for the implementation of early detection programs to identify and treat the disease.

The genotyping of virulence genes showed that in our population the frequency of the cagA gene was lower (59.5\%) than that reported in previous investigations in Colombian mountain regions $33,48,64,65$ and other Latin American countries, with 67 to $80 \%$ reported in patients with premalignant lesions. ${ }^{34,66-68}$ The presence of the cagE gene has been suggested as a better marker than the cagA gene about the integrity of the Cag Pathogenicity Island (cag PAl), and it has been observed with a frequency greater than $80 \%$ in patients with gastrointestinal diseases in other countries. ${ }^{46,69}$ In the present study, $66.3 \%$ of infected patients were positive for cagE, which was lower than in previous reports in Colombian strains. ${ }^{33,54}$ However, the frequency of these genes was significantly higher in patients with severe lesions, and cag $A$ 
was present in $76 \%$ of $\mathrm{PN}$ and $89.8 \%$ in GC, whereas cagE was in $80 \%$ of $\mathrm{PN}$ and $91.8 \%$ in GC. These results are in agreement with previous studies in Colombia ${ }^{33,48}$ and confirm the value of using these genes as markers for PN and GC.

Analysis of the vacA gene alleles showed that in the group of patients with PN and GC, the most frequent combination was $s_{1} m_{1}$, whereas the $s_{2} m_{2}$ genotype was rare; in contrast, in patients with NAG, the most frequent combination was $s_{2} m_{2}$ (Table 2). These results are consistent with those of previous reports, where the $s_{1} m_{1}$ genotype has been widely associated with the presence of chronic inflammation and the development of severe gastric pathologies. ${ }^{70}$ while the vacA $s_{2} m_{2}$ nontoxic strains are more frequent in patients with non-ulcer dyspepsia and mild gastritis. ${ }^{35,71-74}$

The distributions of the tested genes strengthen the observed association of the genes with the disease; thus, the percentage of strains harboring the $\operatorname{cag} A$ and $\operatorname{cag} E$ genes and the $\operatorname{vac} A s_{1} m_{1}$ haplotype increased as the severity of the gastric pathology increased (Fig. 2). A similar trend was previously reported by Cittely et al. ${ }^{48}$ in Colombian patients from Bogotá and in patients with gastroduodenal disorders in other countries. ${ }^{36}$ However, little attention has been paid to the value of $v a c A s_{2} m_{2}$ as a potential marker of disease risk; our results show a strongly significant protective factor of $s_{2} m_{2}$ for PN (OR 0.1544) and even stronger for GC (OR 0.0547) where this vacA haplotype is almost absent. Thus, carrying strains with the $\operatorname{vacA~} s_{2} m_{2}$ haplotype significantly reduces the risk for gastric cancer and to determine vacA alleles there is no need to isolate and culture H. pylori, the test can be done in DNA from biopsies. These make PCR amplification of vacA alleles a useful and accessible biomarker to assess the risk for gastric cancer.

In this study, we analyzed genotype profiles using results from all genes and alleles studied and found as many as 23 genotypes; two of them commonly reported and another 21 different combinations that are less commonly found (Supplementary Fig. 1, Additional File 1). We aimed to see if building a genotype would improve the value of these tests as markers for disease risk. The most frequent genotypes were $\operatorname{cag} A+/ \operatorname{cag} E+/ \operatorname{vacA} s_{1} m_{1}(41 \%)$ and $\operatorname{cag} A-/ \operatorname{cag} E-/ v a c A s_{2} m_{2}(23.9 \%)$. A positive association was found between the severity of these lesions and the $\operatorname{cag} A+/ \operatorname{cag} E+/ \operatorname{vac} A s_{1} m_{1} H$. pylori genotype, while the cagA-/cagE-/vacA $s_{2} m_{2}$ genotype was rare in patients with $\mathrm{PN}$ and $\mathrm{GC}$ and was more frequent in patients with NAG, which supports the relationship between histological features and $H$. pylori genotypes reported in previous studies. $35,71,74,75$

\section{Conclusions}

In conclusion, the present study shows that the $c a g A+/ \operatorname{cag} E+/ v a c A s_{1} m_{1}$ genotype is a marker for increased GC risk, whereas cagA-/cagE-/vacA $s_{2} m_{2}$ is a marker for decreased risk. Of importance, our results suggest that the determination of $\operatorname{vacA}$ alleles is useful enough to evaluate the risk for disease and the presence of $s_{2} m_{2}$ is a strong marker for protection against gastric cancer.

\section{Abbreviations}


$16 s$ rDNA $=$ Subunit 16 of ribosomal DNA

cag $\mathrm{PAl}=$ cag pathogenicity island

$\operatorname{cag} A=$ cytotoxin-associated gene $\mathrm{A}$

cagE= cytotoxin-associated gene $\mathrm{E}$

$\mathrm{GC}=$ gastric cancer

$\mathrm{GCD}=$ diffuse-type gastric cancer

$\mathrm{GCl}=$ intestinal-type gastric cancer

$\mathrm{GCM}=$ mixed-type gastric cancer

H. pylori= Helicobacter pylori

$\mathrm{PCR}=$ polymerase chain reaction

$\mathrm{NAG}=$ non-atrophic gastritis

$\mathrm{PN}=$ preneoplasia

$\operatorname{vac} A=$ vacuolating cytotoxin gene $\mathrm{A}$

$X^{2}=$ The chi-square.

\section{Declarations}

\section{Ethics approval and consent to participate.}

All subjects included in the study provided his/her written informed consent for study participation. Similarly, the study protocol was developed in concordance with The Declaration of Helsinki (subsection of ethics approval and consent to participate).

This study was approved by the bioethics committees of Tolima University with ethical permission number 013 on 23 November 2006; Federico Lleras Acosta Hospital with ethical permission number 18 on 14 February 2010; and the Javeriano Medical Center with ethical permission number 02 on 31 July 2018.

\section{Consent for publication}

Not applicable

\section{Availability of data and materials}


The datasets used and/or analyzed during the current study are available from the corresponding author on reasonable request.

\section{Competing interests}

None declared. The authors declare that they have no competing interests related to the subject matter or materials discussed in this article.

\section{Funding}

Mabel Bohórquez and Magdalena Echeverry received research funding from Tolima University (Projects 30113, 350113, 160114, 10110, 40218 - contract 398-2017); COLCIENCIAS (grant number 110565843382; contract 204 -2015). Javier Torres received funding from the Infectious Diseases Research Unit of the Mexican Institute of Social Security. Luis Carvajal-Carmona receives funding from the National Cancer Institute (grants R01CA223978 and P30CA093373) of the US National Institutes of Health and The Auburn Community Cancer Endowed Chair in Basic Science. Alix A. Guevara-Tique and John J. Suaréz Received funding from the high level of human capital, formation program of Tolima Department, Colciencias, and El Tolima governorate (755-2016).

The content of this article is solely the responsibility of the authors and does not necessarily represent the official views of the National Institutes of Health or any of the funding agencies.

\section{Authors' contributions}

AGT: conceptualization, data curation, formal analysis, funding acquisition, investigation, methodology, project administration, resources, software, supervision, validation, visualization, writing - original draft, writing - review \& editing

FCV: data curation, formal analysis, investigation, methodology, validation, visualization, writing - review \& editing.

JS: data curation, formal analysis, investigation, methodology, validation, visualization, writing - review \& editing.

RT: formal analysis, investigation, methodology, writing - review \& editing.

GP: methodology, resources, writing - review \& editing.

IS: methodology, resources.

JT: conceptualization, investigation, methodology, supervision, validation, writing - original draft, writing review \& editing. 
LC: funding acquisition, investigation, methodology, resources, writing - review \& editing.

MEP: conceptualization, formal analysis, investigation, methodology, writing - original draft, writing review \& editing.

MB: formal analysis, funding acquisition, investigation, methodology, project administration, resources, writing - original draft, writing - review \& editing.

All authors read and approved the final manuscript.

\section{Acknowledgments}

To the patients, doctors, gastroenterologists, and researchers who participated in this study; to the Cytogenetics, Phylogeny and Population Evolution research group from Tolima University; to the Infectious Diseases Research Unit from the Mexican Institute of Social Security for their support; and to the National Cancerological Institute, Bogotá, Colombia, for their donation of DNA from the reference strain NCTC 11638.

\section{References}

1. Ferlay J, Colombet M, Soerjomataram I, Siegel R, Torre L, Jemal A. Global and regional estimates of the incidence and mortality for 38 cancers: GLOBOCAN 2018. Lyon: International Agency for Research on Cancer; 2018.

2. Ferlay J, Colombet $\mathrm{M}$, Soerjomataram I, et al. Estimating the global cancer incidence and mortality in 2018: GLOBOCAN sources and methods. Int J Cancer 2019; 144:1941-1953.

3. Lott, P. C., \& Carvajal-Carmona, L. G. (2018). Resolving gastric cancer etiology: an update in genetic predisposition. The Lancet Gastroenterology \& Hepatology, 3(12), 874-883.

4. Instituto Nacional de Cancerología. Análisis de la situación del cáncer en Colombia 2015. Bogotá, Colombia: Instituto Nacional de Cancerología ESE; 2017.

5. Torres J, Correa P, Ferreccio C, et al. Gastric cancer incidence and mortality is associated with altitude in the mountainous regions of Pacific Latin America. Cancer Causes Control 2013; 24:249-256.

6. IARC. Schistosomes, liver flukes, and Helicobacter pylori. Lyon: International Agency for Research on Cancer; 1994.

7. Sipponen P. Gastric cancer - a long-term consequence of Helicobacter pylori infection? Scand J Gastroenterol 1994; 29:24-27.

8. Bravo LE, Muñoz N. Epidemiology of cancer in Colombia. Colomb Med 2018; 49:9-12.

9. Correa P. Gastric cancer: overview. Gastroenterol Clin N Am 2013; 42:211-217.

10. Kodaman N, Pazos A, Schneider BG, et al. Human, and Helicobacter pylori coevolution shapes the risk of gastric disease. Proc Natl Acad Sci U S A 2014; 111:1455-1460.

11. Vergara-Dagobeth E, Suárez-Causado A, Gómez-Arias R. D. (2017). Plan Control del cáncer en Colombia 2012-2021. Un análisis formal. Revista Gerencia y Políticas de Salud, 16(33), 6-18. 
12. Pardo C, De Vries E, Buitrago L, Gamboa O. Atlas de mortalidad por cáncer en Colombia. Bogotá: Instituto Nacional de Cancerología; 2017.

13. Pardo C, Cendales R. Estimaciones de incidencia y mortalidad para los principales cinco tipos de cáncer en Colombia, 2007-2011. Colomb Méd 2018; 49:16-22.

14. Roldán IJ, Castaño R, Navas MC. Mutaciones del gen ARN ribosómico 23S de Helicobacter pylori asociadas con resistencia a claritromicina en pacientes atendidos en una unidad de endoscopia de Medellín, Colombia. Biomédica 2019; 39:117-129.

15. Correa P, Piazuelo MB. Evolutionary history of the Helicobacter pylori genome: implications for gastric carcinogenesis. Gut Liver 2012; 6:21-28.

16. Hooi JKY, Lai WY, Ng WK, et al. Global prevalence of Helicobacter pylori infection: systematic review and meta-analysis. Gastroenterology 2017; 153:420-429.

17. Bravo LE, Cortés A, Carrascal E, et al. Helicobacter pylori: patología y prevalencia en biopsias gástricas en Colombia. Colomb Méd 2003; 34:124-131.

18. Campuzano-Maya G, Hoyos-Castaño D, Calvo-Betancur VD, Suárez-Ramírez OA, Lizcano-Cardona D, Rojas-Arbeláez CA. Prevalence of Helicobacter pylori infection in physicians in Medellín, Colombia. Acta Gastroenterol Latinoam 2007; 37:99-103.

19. Sicinschi LA, Correa P, Peek RM, et al. CagA C-terminal variations in Helicobacter pylori strains from Colombian patients with gastric precancerous lesions. Clin Microbiol Infect 2009; 16:369-378.

20. Chaturvedi R, de Sablet T, Asim M, et al. Increased Helicobacter pylori-associated gastric cancer risk in the Andean region of Colombia is mediated by spermine oxidase. Oncogene 2015; 34:3429-3440.

21. Correa P, Cuello C, Duque E, et al. Gastric cancer in Colombia. III. Natural history of precursor lesions. JNCI: J Natl Cancer Inst 1976; 57:1027-1035.

22. Cuello C, Correa P, Haenszel W, et al. Gastric cancer in Colombia. I. Cancer risk and suspect environmental agents. J Natl Cancer Inst 1976; 57:1015-1020.

23. de Sablet T, Piazuelo MB, Shaffer CL, et al. Phylogeographic origin of Helicobacter pylori is a determinant of gastric cancer risk. Gut 2011; 60:1189-1195.

24. Goodman KJ, Correa P, Aux HJT, et al. Helicobacter pylori infection in the Colombian Andes: a population-based study of transmission pathways. Am J Epidemiol 1996; 144:290-299.

25. Sicinschi LA, Correa P, Peek RM, Jr., et al. Helicobacter pylori genotyping and sequencing using paraffinembedded biopsies from residents of Colombian areas with contrasting gastric cancer risks. Helicobacter 2008; 13:135-145.

26. Censini S, Lange C, Xiang Z, et al. cag, a pathogenicity island of Helicobacter pylori, encodes type Ispecific and disease-associated virulence factors. Proc Natl Acad Sci U S A 1996; 93:14648-14653.

27. Ding SZ, Zheng PY. Helicobacter pylori infection-induced gastric cancer; advance in gastric stem cell research and the remaining challenges. Gut Pathog 2012; 4:18.

28. Hatakeyama M. Helicobacter pylori and gastric carcinogenesis. J Gastroenterol 2009; 44:239-248.

29. Akazawa Y, Isomoto H, Matsushima K, et al. Endoplasmic reticulum stress contributes to Helicobacter pylori VacA-induced apoptosis. PLoS One 2013;8: e82322.

Page 13/18 
30. Cover TL, Blanke SR. Helicobacter pylori VacA, a paradigm for toxin multifunctionality. Nat Rev Microbiol 2005; 3:320-332.

31. Radin JN, González-Rivera C, Ivie SE, McClain MS, Cover TL. Helicobacter pylori VacA induces programmed necrosis in gastric epithelial cells. Infect Immun 2011; 79:2535-2543.

32. Delgado APM, Henao CAJ, Perafán MDPD, Lozano MEB, Torres AÁ. Detección y genotipificación de Helicobacter pylori sobre la base de los genes ADNr $16 \mathrm{~S}$ y el gen asociado a citotoxina (cagA) y posible asociación con enfermedades gastrointestinales. Rev Cuba Med Trop 2008; 60:105-110.

33. Quiroga AJ, Cittelly DM, Bravo MM. Frecuencia de los genotipos babA2, oipA y cagE de Helicobacter pylori en pacientes colombianos con enfermedades gastroduodenales. Biomédica 2005; 25:325-334.

34. Con SA, Valerín AL, Takeuchi $\mathrm{H}$, et al. Helicobacter pylori CagA status associated with gastric cancer incidence rate variability in Costa Rican regions. J Gastroenterol 2006; 41:632-637.

35. Sheikh AF, Yadyad MJ, Goodarzi H, et al. CagA and vacA allelic combination of Helicobacter pylori in gastroduodenal disorders. Microb Pathog 2018;122:144-150.

36. Pormohammad A, Ghotaslou R, Leylabadlo HE, Nasiri MJ, Dabiri H, Hashemi A. Risk of gastric cancer in association with Helicobacter pylori different virulence factors: a systematic review and meta-analysis. Microb Pathog 2018; 118:214-219.

37. Falush D, Wirth T, Linz B, et al. Traces of human migrations in Helicobacter pylori populations. Science 2003; 299:1582-1585.

38. Jones KR, Whitmire JM, Merrell DS. A tale of two toxins: Helicobacter pylori CagA and VacA modulate host pathways that impact disease. Front Microbiol 2010; 1:115.

39. Palframan SL, Kwok T, Gabriel K. Vacuolating cytotoxin A (VacA), a key toxin for Helicobacter pylori pathogenesis. Front Cell Infect Microbiol 2012; 2:92.

40. López AM, Delgado MP, Jaramillo C, Amézquita A, Parra G, Echeverry MM. Caracterización del gen de la citotoxina vacuolizante de Helicobacter pylori a partir de biopsias gástricas de pacientes residentes en Tolima, Colombia. Rev Argent Microbiol 2009; 41:4-10.

41. Montealegre OMC, Jaramillo HCA, Montealegre LG, Parra GG, Echeverry MM, Delgado MDP. Detección histológica y molecular de Helicobacter pylori y genotipificación con base en los genes de virulencia babA2 e iceA en pacientes con patología gástrica benigna. Rev Chil Infectol 2010; 27:112-118.

42. Montealegre Ortiz MC, Jaramillo Henao C, Bohórquez Lozano ME, Montealegre Lynett G, Delgado MDP. Detección de Helicobacter pylori y caracterización del la región-31 del gen de la Interleucina 1-ß humana en pacientes de una población colombiana con enfermedades gastroduodenales. Rev Colomb Gastroenterol 2008; 23:40-44.

43. Hou P, Tu ZX, Xu GM, Gong YF, Ji XH, Li ZS. Helicobacter pylori vacA genotypes and cagA status and their relationship to associated diseases. World J Gastroenterol 2000; 6:605-607.

44. Correa P. Human gastric carcinogenesis: a multistep and multifactorial process-first American cancer society award lecture on cancer epidemiology and prevention. Cancer Res 1992; 52:6735-6740.

45. Correa P, Haenszel W, Cuello C, Tannenbaum S, Archer M. A model for gastric cancer epidemiology. Lancet $1975 ; 306: 58-60$. 
46. Bakhti SZ, Latifi-Navid S, Safaralizadeh R. Helicobacter pylori-related risk predictors of gastric cancer: the latest models, challenges, and future prospects. Cancer Med 2020; 9:4808-4822.

47. Bravo LE, Doorn LJ, Realpe JL, Correa P. Virulence-associated genotypes of Helicobacter pylori: do they explain the African enigma? Am J Gastroenterol 2002; 97:2839-2842.

48. Cittelly DM, Huertas MG, Martínez JD, et al. Los genotipos de Helicobacter pylori en gastritis no atrófica difieren de los encontrados en úlcera péptica, lesiones premalignas y cáncer gástrico en Colombia. Rev Méd Chile 2002; 130:143-151.

49. Nogueira C, Figueiredo C, Carneiro F, et al. Helicobacter pylori genotypes may determine gastric histopathology. Am J Pathol 2001;158: 647-654.

50. Pérez F. Jeografia fisica i política del Distrito federal, capital de los Estados Unidos de Colombia: escrita de orden del gobierno jeneral. Bogotá: Imprenta de la Nación; 1863.

51. Salazar I. Geografía económica de la región andina oriental. Bogotá: Banco de la República-Economía Regional; 2010.

52. Molina Delgado AP. Detección y Genotipificación de Helicobacter pylori en base a los genes ADNr 16S y el gen asociado a citotoxina (cagA) y posible asociación con patologías gastrointestinales. Bogotá: Uniandes; 2008.

53. Cover TL. Helicobacter pylori diversity and gastric cancer risk. mBio 2016;7:e01869-01815.

54. Fajardo CA, Quiroga AJ, Coronado A, et al. CagA EPIYA polymorphisms in Colombian Helicobacter pylori strains and their influence on disease-associated cellular responses. World J Gastrointest Oncol 2013; 5:50-59.

55. Cheng X, Zheng Z, Bu Z, et al. LAPTM4B-35, a cancer-related gene, is associated with poor prognosis in TNM stages I-III gastric cancer patients. PLoS One 2015;10: e0121559.

56. Rizzato C, Kato I, Plummer M, Muñoz N, Canzian F. Genetic variation in PSCA and risk of gastric advanced preneoplastic lesions and cancer in relation to Helicobacter pylori infection. PLoS One 2013;8:e73100.

57. Rodríguez-Vargas B, Arévalo-Suarez F, Monge-Salgado E, Montes-Teves P. Características histológicas y endoscópicas del cáncer gástrico diagnosticado en un hospital nacional del Callao, Perú. Rev Peru Med Exp Salud Publica 2013; 30:12-17.

58. Song HR, Kim HN, Kweon SS, et al. Genetic variations in the PRKAA1 and ZBTB20 genes and gastric cancer susceptibility in a Korean population. Mol Carcinog 2013; 52:155-160.

59. Brome Bohórquez MR, Montoya Restrepo DM, Amell L. Cancer incidence and mortality in MedellinColombia, 2010-2014. Colomb Méd 2018; 49:81-88.

60. Martínez Marín JD, Garzón Olarte MA, Lizarazo Rodríguez JI, et al. Characteristics of patients with gastric cancer referred to the hospital universitario de la Samaritana in Cundinamarca department from 2004 to 2009. Rev Colomb Gastroenterol 2010; 25:344-348.

61. Flores-Luna L, Bravo MM, Kasamatsu E, et al. Risk factors for gastric precancerous and cancers lesions in Latin American countries with difference gastric cancer risk. Cancer Epidemiol 2020; 64:101630. 
62. Marulanda H, Otero W, Gómez M. Helicobacter pylori, gastritis nodular y lesiones premalignas de estómago: un estudio de casos y controles. Rev Gastroenterol Perú 2018; 38:349-355.

63. Rojas-Rengifo DF, Mendoza B, Jaramillo C, et al. Helicobacter pylori culture as a key tool for diagnosis in Colombia. J Infect Dev Ctries 2019; 13:720-726.

64. Galvis AA, Trespalacios-Rangel AA, Otero W, Mercado-Reyes MM, Poutou-Piñales RA. Prevalence of cagA, vacA, babA2, and iceA genes in $\mathrm{H}$. pylori strains isolated from Colombian patients with functional dyspepsia. Pol J Microbiol 2012; 61:33-40.

65. Trujillo E, Martínez T, Bravo MM. Genotipificación de los factores de virulencia vacA y cagA de Helicobacter pylori en individuos de dos regiones de Colombia con riesgo opuesto de cáncer gástrico. Biomédica 2014; 34:567-573.

66. Martínez Echavarría MT, González Torres M, Ferreira Capote R, Mas Páez JA. Genotipo cag A+ en cepas de Helicobacter pylori asociadas a úlcera péptica, gastritis crónica y cáncer gástrico. Rev Cuba Med 2008; 47(2), 0-0.

67. Ribeiro ML, Godoy APO, Benvengo YHB, Mendonça S, Pedrazzoli J. Clinical relevance of the cag A, vac A and ice A genotypes of Helicobacter pylori in Brazilian clinical isolates. FEMS Immunol Med Microbiol 2003; 36:181-185.

68. Zaki MES, Rizk MA, Bakr AO, Mahmoud M, Ali MA, Shehta A. Molecular study of Helicobacter pylori virulence genes CagA, Hpa and BabA2 in Egyptian patients. Afr J Clin Exp Microbiol 2018; 19:274-281.

69. GholizadeTobnagh S, Bakhti SZ, Navid SL, Zahri S, Bakhti FS. Role of plasticity region genes and cagE gene of cagPAl of Helicobacter pylori in development of gastrointestinal (GI) diseases. Asian Pac J Cancer Prev: APJCP 2017; 18:43-49.

70. Yamaoka Y, Kodama T, Gutierrez O, Kim JG, Kashima K, Graham DY. Relationship between Helicobacter pylori iceA, cagA, and vacA status and clinical outcome: studies in four different countries. J Clin Microbiol 1999; 37:2274-2279.

71. Atrisco-Morales J, Martínez-Santos VI, Román-Román A, et al. vacA s1m1 genotype and cagA EPIYA$A B C$ pattern are predominant among Helicobacter pylori strains isolated from Mexican patients with chronic gastritis. J Med Microbiol 2018; 67:314-324.

72. Bustamante-Rengifo JA, Matta AJ, Pazos AJ, Bravo LE. Effect of treatment failure on the CagA EPIYA motif in Helicobacter pylori strains from Colombian subjects. World J Gastroenterol 2017; 23:19801989.

73. Melo-Narváez MC, Rojas-Rengifo DF, Jimenéz-Soto LF, et al. Genotipificación de cagA y de la región intermedia de vacA en cepas de Helicobacter pylori aisladas de pacientes adultos colombianos y asociación con enfermedades gástricas. Rev Colomb Gastroenterol 2018; 33:103-110.

74. Román-Román A, Martínez-Carrillo DN, Atrisco-Morales J, et al. Helicobacter pylori vacA s1m1 genotype but not cagA or babA2 increase the risk of ulcer and gastric cancer in patients from Southern Mexico. Gut Pathog 2017; 9:18.

75. Carlosama-Rosero YH, Bolaños-Bravo H, Sierra-Tórres CH, Rosero EA. Asociación de los genotipos cagA, vacA e IceA de $H$. pylori con la gastritis crónica y folicular en una población colombiana con alto riesgo de cáncer gástrico. Rev Gastroenterol Méx 2019; 84:158-164. 
Figures

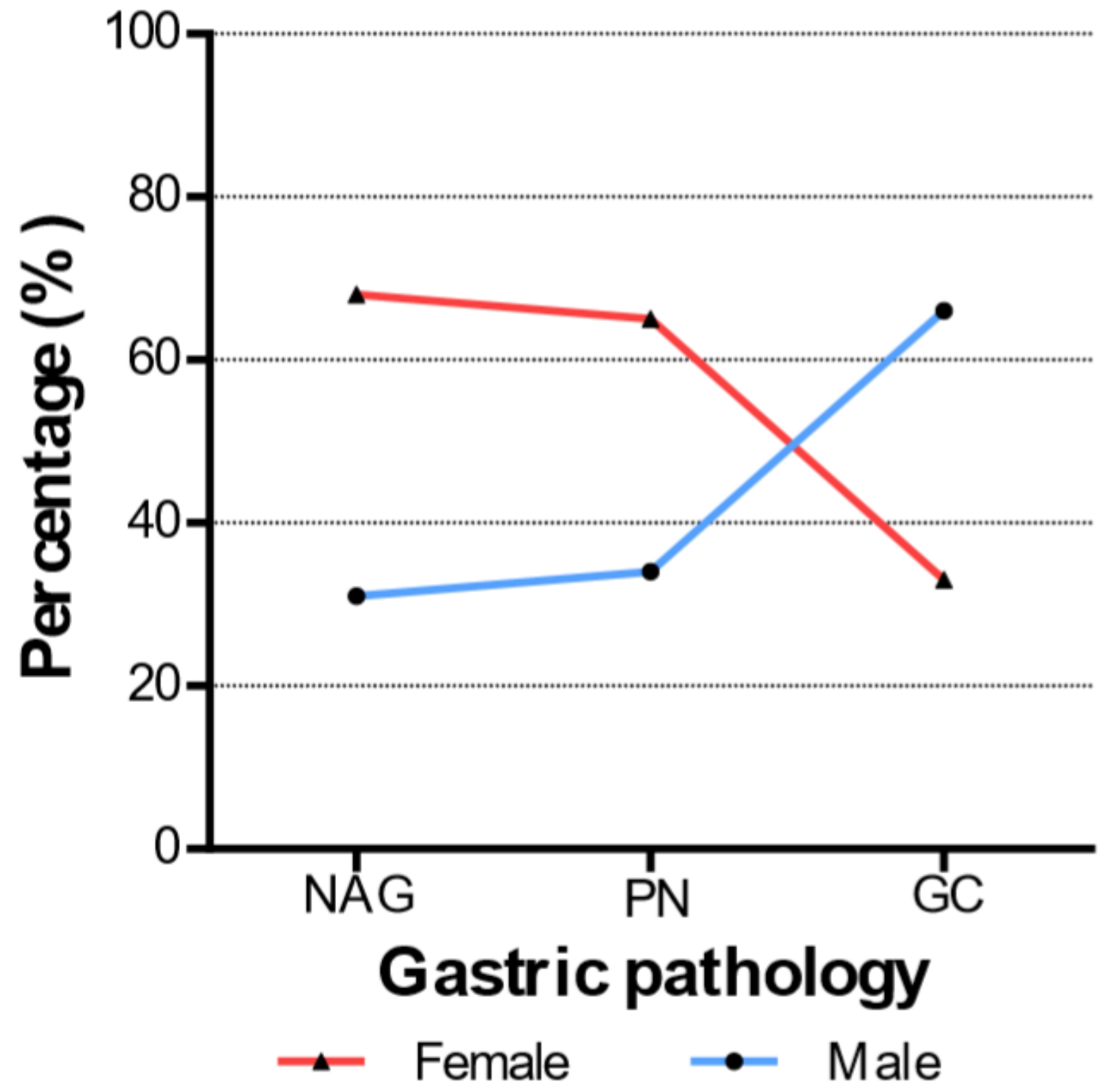

Figure 1

Distribution of sample according to gastric pathology and sex $(n=466)$. 


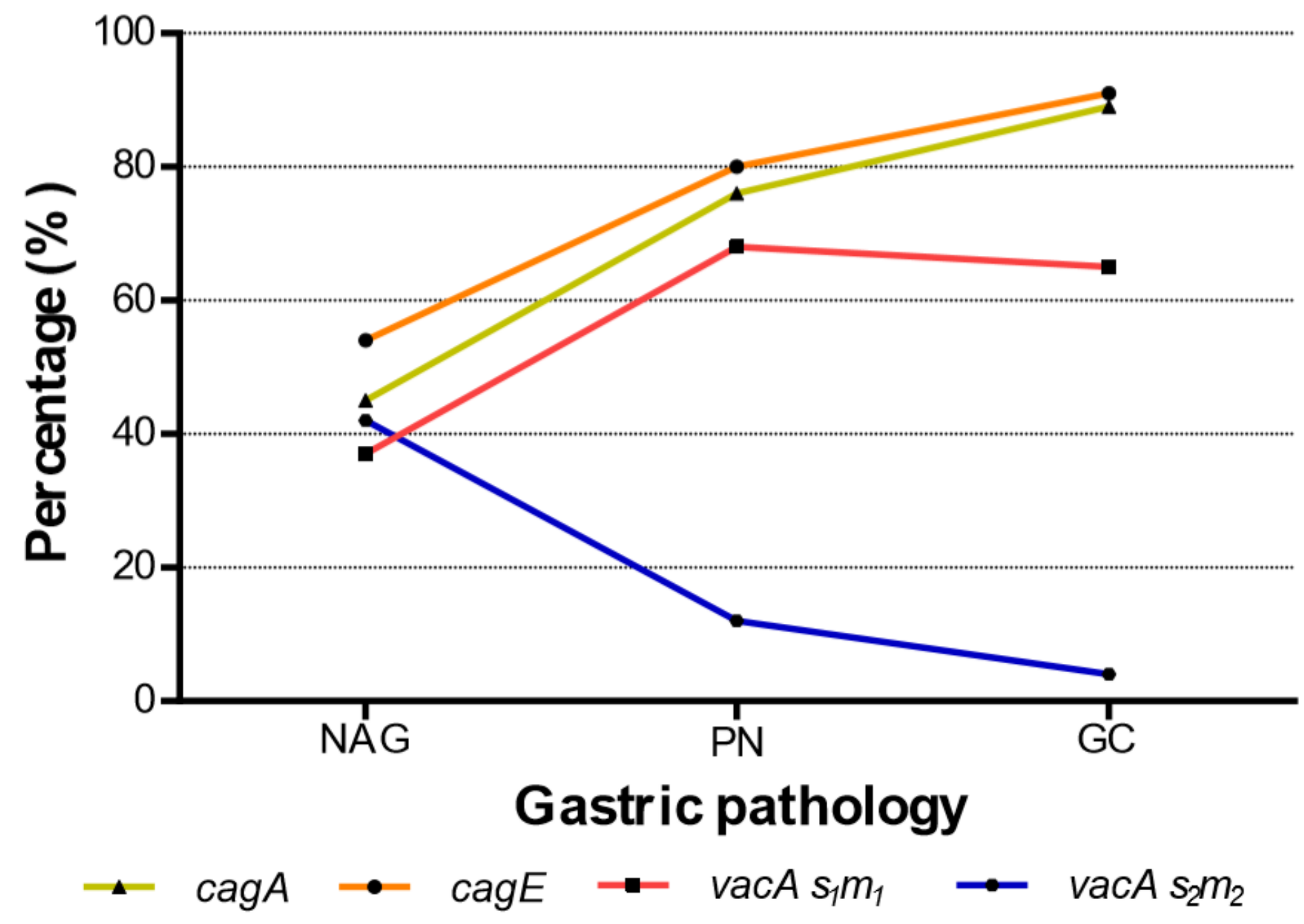

Figure 2

Frequency of $\mathrm{H}$. pylori strains with the genescagA, cagE, and $\mathrm{s} 1 \mathrm{~m} 1$ ands $2 \mathrm{~m} 2$ vacA haplotypes in infected patients according to their clinical group.

\section{Supplementary Files}

This is a list of supplementary files associated with this preprint. Click to download.

- AdditionalFile1.pdf 